\title{
Water Quality Deterioration in Artificial Lake: Their Impact and Sources
}

\author{
Nor Azlina Abd Aziz*, Mohd Ekhwan Toriman*, Muhammad Barzani Gasim, Soaad Muftah", Amal \\ Barggig", Mohd Khairul Amri Kamarudin ${ }^{\#}$ \\ ${ }^{\#}$ East Coast Environmental Research Institute (ESERI), Universiti Sultan Zainal Abidin, Gong Badak Campus, 21300 Terengganu, Malaysia \\ E-mail:drbarzani@gmail.com,mkhairulamri@unisza.edu.my \\ *School of Social, Development and Environmental Studies, Faculty of Social Sciences and Humanities, Universiti Kebangsaan Malaysia, \\ 43600 Bangi, Selangor, Malaysia \\ E-mail: azlina82aziz@gmail.com,ekhwantoriman@gmail.com,soadmuftah@gmail.com,amalbarggig@gmail.com
}

${ }^{\#}$ Faculty of Bio Resources and Food Industries, Universiti Sultan Zainal Abidin, Tembila Campus, 22200 Besut, Terengganu, Malaysia ${ }^{\#}$ Faculty of Design Arts and Engineering Technology, Universiti Sultan Zainal Abidin, Gong Badak Campus, 21300 Terengganu, Malaysia

\begin{abstract}
Seven sampling stations were identified to determine the status of water quality in Cempaka Lake, Bandar Baru Bangi within two sampling periods of June 2010 and August 2010. The objectives of the study are to identify and classify the current water quality in the lake. A total of twelve water quality parameters have been analyzed in-situ and ex-situ and classified under WQI and NWQS classifications, four parameters were analyzed using HYDROLAB meter DataSonde, eight parameters were analyzed under the standard of the HACH and APHA methods. The results are pH between 6.13 to 6.92, DO 1.63 to $4.94 \mathrm{mg} / \mathrm{L}$, temperature 26.02 to $28.37^{\circ} \mathrm{C}$, conductivity of 94 to $213 \mu \mathrm{S} / \mathrm{cm}$, BOD 0.38 up to $2.4 \mathrm{mg} / \mathrm{L}$, NH3-N 2.00 to $2.84 \mathrm{mg} / \mathrm{L}$, phosphate 0.21 to $0.56 \mathrm{mg} / \mathrm{L}$, sulphate 21 to $35 \mathrm{mg} / \mathrm{L}$, COD 9.3 to $69 \mathrm{mg} / \mathrm{L}$, TSS of 1.8 to $33.3 \mathrm{mg} / \mathrm{L}$, oil and grease 5.7 to $11.8 \mathrm{mg} / \mathrm{L}$ and hardness 13.89 to $35.57 \mathrm{mg} / \mathrm{L}$. Based on this classification, the water quality of Cempaka Lake was classified as Class II and III. The results are clearly shown that the majority of the water quality parameters in the study area are more polluted during the first sampling compared to the second sampling. Cempaka Lake has been contaminated due to residential activities, clinic centres, restaurants, petrol pump stations that release discharge into streams, rivers and eventually the lake become a brownish color and a smell of ammonia.
\end{abstract}

Keywords - Cempaka Lake; water quality parameters; water quality pollution; WQI; NWQS classifications

\section{INTRODUCTION}

Water is vital to the human's existence. Early human civilizations were centered on spring and streams. Many civilizations that flourished after developing reliable water supply collapsed when the supply was exhausted or its quality deteriorated [1]. The fast growth of urban areas has affected the water quality of the surface water due to overexploitation of resources and improper waste disposal practices. The catchment area is important for water resource conservation, both in terms of quality and quantity.

The study of water quality aspects of the water distribution system is of great significance as it plays an important role in assuring a good quality of water to the consumer [2]-[5]. Water quality is important in drinking water supply, irrigation, fish production, recreation and other purposes to which the water must have been impounded. Water quality is determined by the physical and chemical limnology and includes all physical, chemical and biological factors of water that influence the beneficial use of the water [6]. The destruction of catchment area will lead to the deterioration in quality and quantity of the water resource further downstream [7].

In general, the status of water quality can provide useful information on land activities within the catchment area, for example, the deterioration of water quality at Tasik Chini have been raising due to their correlated with agriculture and mining activities [8]. About one-third of the drinking water requirement of the world is obtained from surface sources like rivers, canals, and lakes. Unfortunately, these sources seem to be used as the best place for waste discharge for agriculture, domestics, and industries [9].

In general, the status of water quality at each of the sampling site could provide useful information on land activities within the lake's catchment area. It is believed that at the catchment studied, higher concentrations of the DO, 
for example, was triggered by intensive agriculture activities which resulted in changes to land use and land cover [10]. In [11] was conducting research on the suitability of quality of the Petanu River in Bali, Indonesia for the agricultural use.

Water quality index is one of the most effective tools to communicate information on the quality of water to the concerned citizens and policy makers. It becomes a significant parameter for the assessment and management of surface water [1].

WQI is defined as a rating that reflects the complex influence of different water quality parameters. WQI is calculated from the point of vision of the suitability of surface water for human consumption [12]. Water quality classification in all seasons where the quality slightly differs in summer and winter compared to the post monsoon season are reasons to introduce water quality change and measures to be taken in terms of the groundwater quality management [13].

Discharge of toxic chemicals over pumping of aquifer and contamination of water bodies with a substance that promotes algae growth are some of the today's major cause for the degradation of water quality. Direct contamination of surface water with metals in discharges of mining, smelting and industrial manufacturing is a long-standing phenomenon [14]. Today, there are traces of contamination not only of surface water but also of groundwater bodies which are susceptible to leach from waste dumps, mine tailings, and industrial production sites [15].
The physical and chemical properties of water resources are driven by numerous environmental variables such as climate, wastewater effluent and tidal effect at the estuary [16]. The main purpose of analyzing the physical, chemical and microbiological characteristics of water is to determine its nutrient status. Since the water contains both dissolved and suspended materials in various proportions, its physical and chemical characteristics differ along with its biological characteristics [17].

Cempaka Lake, Bangi is a man-made lake which located between the commercial centre and Kompleks Perbadanan Kemajuan Negeri Selangor (PKNS) Jabatan Kemajuan Bangi (Fig. 1). The lake originated from a small river called Sg. Ayer Hitam. It was then upgraded into a lake which covered about 15.7 acres of land. The length of the lake from the inlet to outlet is about $700 \mathrm{~m}$ with maximum depth 3 meters in the middle. The lake is connected with Sungai Langat through Sg. Ramal, a shallow river that runs through Kajang and Bangi areas.

Flood always occurs when there are heavy rains. Thus, Cempaka reacts as a retention pond by slowing down the water flow into Sungai Langat. Later on, the area is made into a recreational park. Today, the Cempaka Lake serves the local people recreation or as an infrastructure for social activities such as jogging, fishing, fitness training and a playground area for children.

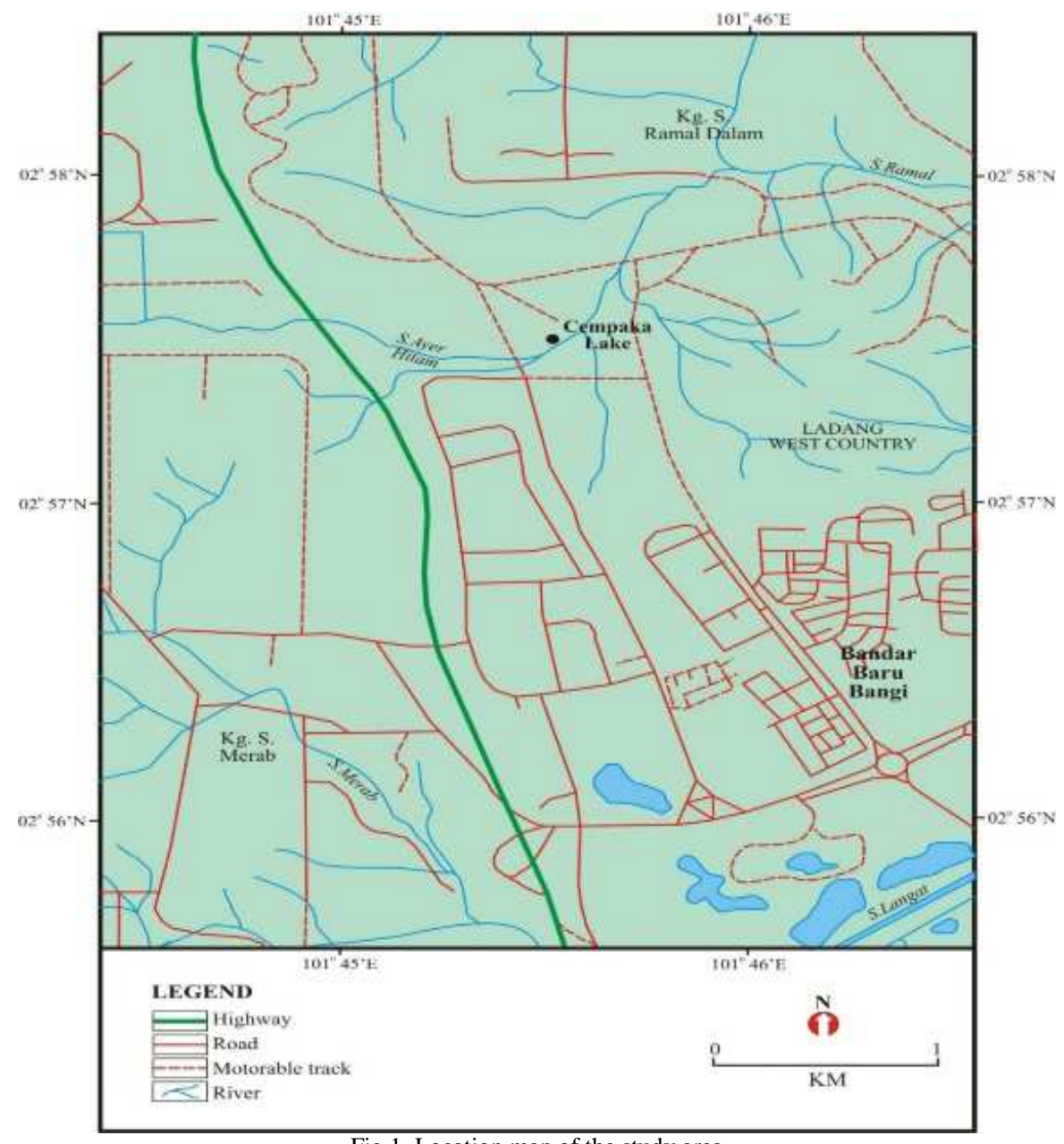

Fig.1 Location map of the study area 


\section{MATERIAL AND METHOD}

Seven sampling stations were chosen from the surrounding the lake (station 1 to station 7) as shown in (Fig. 2). Station 1 was located at the inlet area of the lake, four sampling stations (station 2 to station 5) in the surrounding of the lake and Station 6 was in the centre, the last station, St. 7 was located at the outlet of the lake. The samples were taken using polyethylene bottles which had been soaked and cleaned before the sampling. After the collection, the samples were immediately placed into ice boxes and processed for immediate analysis in the laboratory. The water samples were collected at a range of time from 8:30 to $10 \mathrm{am}$. Three replications of the sample were taken randomly at each station.

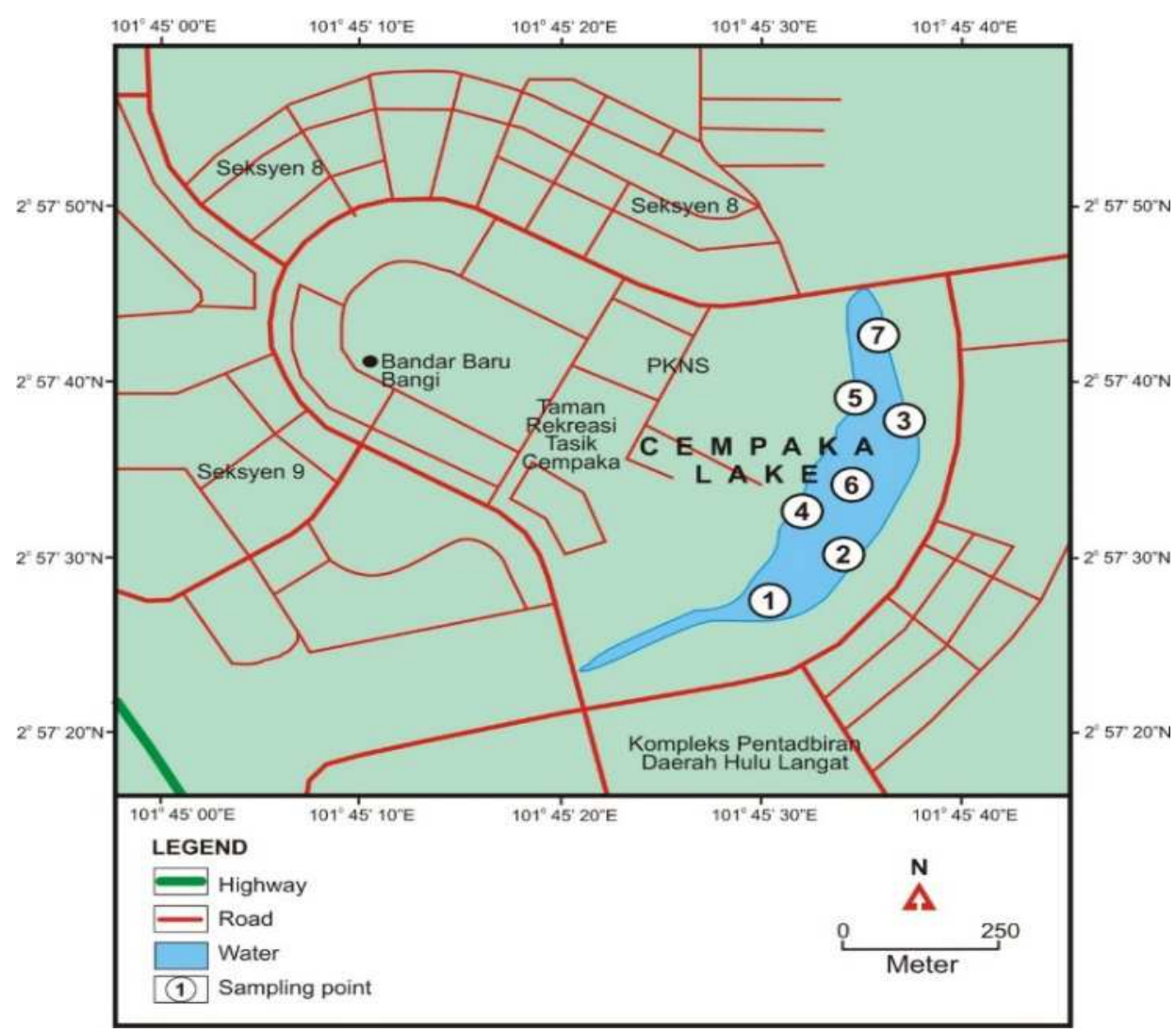

Fig. 2 Location of seven water sampling stations in the Cempake Lake

The water quality analysis is divided into two measurements. In-situ measurement and water samples were taken to the ESERI lab for the purpose of laboratory analysis. Four water quality parameters (temperature, $\mathrm{pH}$, dissolved oxygen and electrical conductivity) were measured in-situ using HYDROLAB meter DataSonde. Eight chemical parameters such as chemical oxygen demand (COD), biochemical oxygen demand (BOD), hardness, sulphate (SO4), ammoniacal nitrogen (NH3-N), phosphate (PO4), oil and grease and other parameter was total suspended solids (TTS) were analyzed in the laboratory [18]. All the analyses were performed in accordance with the standard methods. COD was analysed by the dichromate reflux; BOD by BOD test; hardness by the EDTA titrimetric; SO4, NH3-N, PO4 by salicylate (HATCH KIT DR 2010); oil and grease by Hexane Extractable Gravimetric and TSS by Gravimetric methods.

\section{RESULTS AND DISCUSSION}

Four water quality parameters; temperature, $\mathrm{pH}, \mathrm{DO}$ and conductivity; were measured in-situ (during sampling) to get the best fit result in this study.

\section{A. Temperature}

The range of temperature value during first sampling was from 26.02 to $27.82^{\circ} \mathrm{C}$ with an average of $26.98^{\circ} \mathrm{C}$, which the highest $\left(27.82^{\circ} \mathrm{C}\right)$ was recorded at St. 7 and the lowest $\left(26.02^{\circ} \mathrm{C}\right)$ was recorded at St. 1 . The range of temperature value during the second sampling was from $27.62^{\circ} \mathrm{C}$ to $28.37^{\circ} \mathrm{C}$ with an average of $28.04{ }^{\circ} \mathrm{C}$, where the highest $\left(28.37^{\circ} \mathrm{C}\right)$ was recorded at St. 3 and St.7 and the lowest $\left(27.62^{\circ} \mathrm{C}\right)$ was recorded at St. 1 (Fig. 3a).

\section{B. $p H$}

The range of $\mathrm{pH}$ value during first sampling was from 6.13 to 6.88 with an average of 6.59 , where the highest (6.88) was recorded at St. 6 and the lowest (6.13) was recorded at St. 1 . The range of $\mathrm{pH}$ value during the second sampling was from 6.40 to 6.92 with an average of 6.66 , which the highest (6.92) was recorded at St. 6 and the lowest (6.40) was recorded at St. 1 (Fig. 3b).

\section{Dissolved Oxygen (DO)}

The range of dissolved oxygen value during the first sampling was from 3.76 to $4.94 \mathrm{mg} / \mathrm{L}$ with an average of 
$4.34 \mathrm{mg} / \mathrm{L}$, where the highest $(4.94 \mathrm{mg} / \mathrm{L})$ was recorded at St. 1 and the lowest $(3.76 \mathrm{mg} / \mathrm{L})$ was recorded at St. 7 . The range of dissolved oxygen during the second sampling was from 1.63 to $2.73 \mathrm{mg} / \mathrm{L}$ with an average of $2.14 \mathrm{mg} / \mathrm{L}$, which the highest $(2.73 \mathrm{mg} / \mathrm{L})$ was recorded at St. 4 and the lowest $(1.63 \mathrm{mg} / \mathrm{L})$ was recorded at St. 1 (Fig. 3c).

\section{Conductivity (EC)}

The range of conductivity value during the first sampling was from 94 to $212 \mu \mathrm{S} / \mathrm{cm}$ with an average of $168.42 \mu \mathrm{S} / \mathrm{cm}$, which the highest $(212 \mu \mathrm{S} / \mathrm{cm})$ was recorded at St. 6 and the lowest $(94 \mu \mathrm{S} / \mathrm{cm})$ was recorded at St. 1 . The range of conductivity during the second sampling was from 142.6 to $186 \mu \mathrm{S} / \mathrm{cm}$ with an average of $153.9 \mu \mathrm{S} / \mathrm{cm}$, where the highest $(186 \mu \mathrm{S} / \mathrm{cm})$ was recorded at St. 1 and the lowest $(142.6 \mu \mathrm{S} / \mathrm{cm})$ was recorded at St. 7 (Fig. 3d).
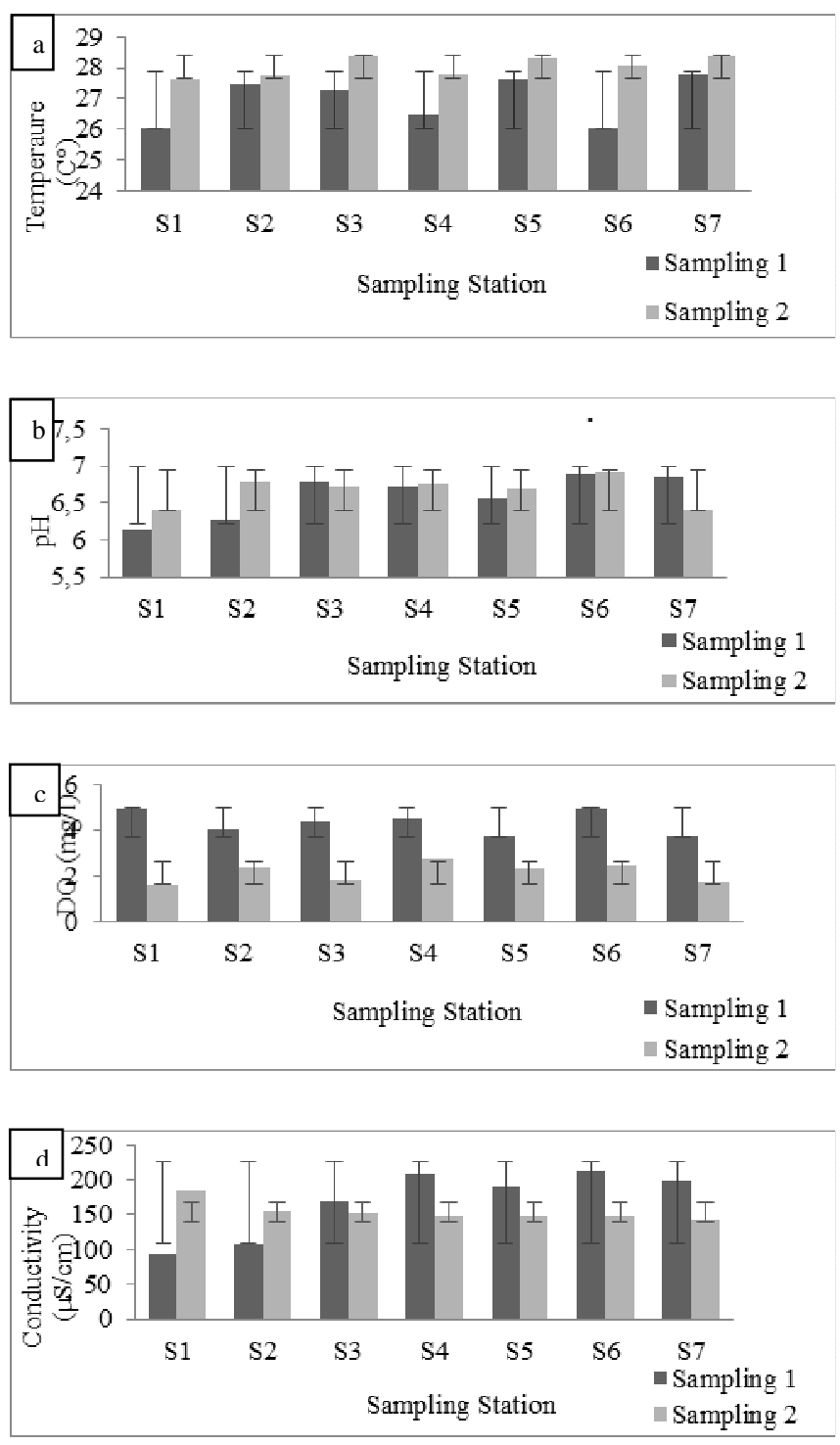

Fig. 3 Distribution of in-situ water quality parameters between two samplings temperature (a), $\mathrm{pH}$ (b), DO (c) and conductivity (d)

\section{E. Chemical Oxygen Demand (COD)}

The range of Chemical Oxygen Demand during the first sampling was from 2.7 to $69 \mathrm{mg} / \mathrm{L}$ with an average of 30.08 $\mathrm{mg} / \mathrm{L}$. The highest $(69 \mathrm{mg} / \mathrm{L})$ was recorded at station 7 and the lowest $(2.7 \mathrm{mg} / \mathrm{L})$ was recorded at station 1 . The range of Chemical Oxygen Demand during the second sampling was from 9.3 to $22.6 \mathrm{mg} / \mathrm{L}$ with an average of $14.25 \mathrm{mg} / \mathrm{L}$. The highest $(22.6 \mathrm{mg} / \mathrm{L})$ was recorded at station 5 and the lowest $(9.3 \mathrm{mg} / \mathrm{L})$ was recorded at station 2 (Fig. $4 \mathrm{a}$ ).

\section{F. Biochemical Oxygen Demand (BOD)}

The range value of the biochemical oxygen demand during the first sampling was from 0.91 to $2.4 \mathrm{mg} / \mathrm{L}$, with an average of $1.43 \mathrm{mg} / \mathrm{L}$, The highest $(2.4 \mathrm{mg} / \mathrm{L})$, was recorded at station 1and the lowest $(0.91 \mathrm{mg} / \mathrm{L})$ was recorded at station 5 . The range of biochemical oxygen demand value during the second sampling was from $0.38 \mathrm{mg} / \mathrm{L}$ to $0.60 \mathrm{mg} / \mathrm{L}$, with an average of 0.50 $\mathrm{mg} / \mathrm{L}$, the highest was $(0.60 \mathrm{mg} / \mathrm{L})$ was recorded at station 2 and the lowest $(0.38 \mathrm{mg} / \mathrm{L})$ was recorded at station 1 as shown in (Fig. 4.b).

\section{G. Total Suspended Solids (TSS)}

The range of total suspended solids during the first sampling was from 1.8 to $33.3 \mathrm{mg} / \mathrm{L}$ with an average of 8.52 $\mathrm{mg} / \mathrm{L}$. The highest $(33.3 \mathrm{mg} / \mathrm{L})$ was recorded at station 2 and the lowest $(1.8 \mathrm{mg} / \mathrm{L})$ was recorded at station 3 . The range of total suspended solids during the second sampling was from 3.7 to $7.6 \mathrm{mg} / \mathrm{L}$ with an average of $4.98 \mathrm{mg} / \mathrm{L}$. The highest $(7.6 \mathrm{mg} / \mathrm{L})$ was recorded at station 7 and the lowest $(3.7 \mathrm{mg} / \mathrm{L})$ was recorded at station 3 (Fig. $4 \mathrm{c}$ ).

\section{H. Hardness $\left(\mathrm{CaCO}_{3}\right)$}

The hardness of water depends mainly upon the amounts of calcium or magnesium salts or both [19]. The range of hardness during the first sampling was from 15.07 to 35.57 $\mathrm{mg} / \mathrm{L}$ with an average of $30.94 \mathrm{mg} / \mathrm{L}$. The highest $(35.57 \mathrm{mg} / \mathrm{L})$ was recorded at station 5 and the lowest $(15.07$ $\mathrm{mg} / \mathrm{L}$ ) was recorded at station 7 . The range of hardness during the second sampling was from 13.89 to $17.01 \mathrm{mg} / \mathrm{L}$ with an average of $16.30 \mathrm{mg} / \mathrm{L}$. The highest $(17.01 \mathrm{mg} / \mathrm{L})$ was recorded at station 6 and the lowest $(13.89 \mathrm{mg} / \mathrm{L})$ was recorded at station 3 (Fig. 4d).

\section{Oil and Grease $(O \& G)$}

The range of oil and grease during the first sampling was from 5.7 to $11.8 \mathrm{mg} / \mathrm{L}$ with an average of $8.17 \mathrm{mg} / \mathrm{L}$. The highest $(11.8 \mathrm{mg} / \mathrm{L})$ was recorded at station 6 and the lowest $(5.7 \mathrm{mg} / \mathrm{L})$ was recorded at station 7 . The range of oil and grease during the second sampling was from 6.6 to $11.4 \mathrm{mg} / \mathrm{L}$ with an average of $8.12 \mathrm{mg} / \mathrm{L}$. The highest $(11.4 \mathrm{mg} / \mathrm{L})$ was recorded at station 6 and the lowest $(6.6 \mathrm{mg} / \mathrm{L})$ was recorded at station 4 and 7 (Fig. 4e).

\section{J. Ammoniacal Nitrogen}

The range of ammoniacal-nitrogen during the first sampling was from 2.56 to $2.84 \mathrm{mg} / \mathrm{L}$ with an average of $2.69 \mathrm{mg} / \mathrm{L}$. The highest $(2.84 \mathrm{mg} / \mathrm{L})$ was recorded at station 3 and the lowest $(2.56 \mathrm{mg} / \mathrm{L})$ was recorded at station 2 . The range of ammoniacal-nitrogen during the second sampling was from $2.00 \mathrm{mg} / \mathrm{L}$ to $2.46 \mathrm{mg} / \mathrm{L}$ with an average of 2.23 $\mathrm{mg} / \mathrm{L}$. The highest $(2.46 \mathrm{mg} / \mathrm{L})$ was recorded at station 1 and the lowest ( $2.00 \mathrm{mg} / \mathrm{L}$ ) was recorded at station 5 (Fig. 5a). 

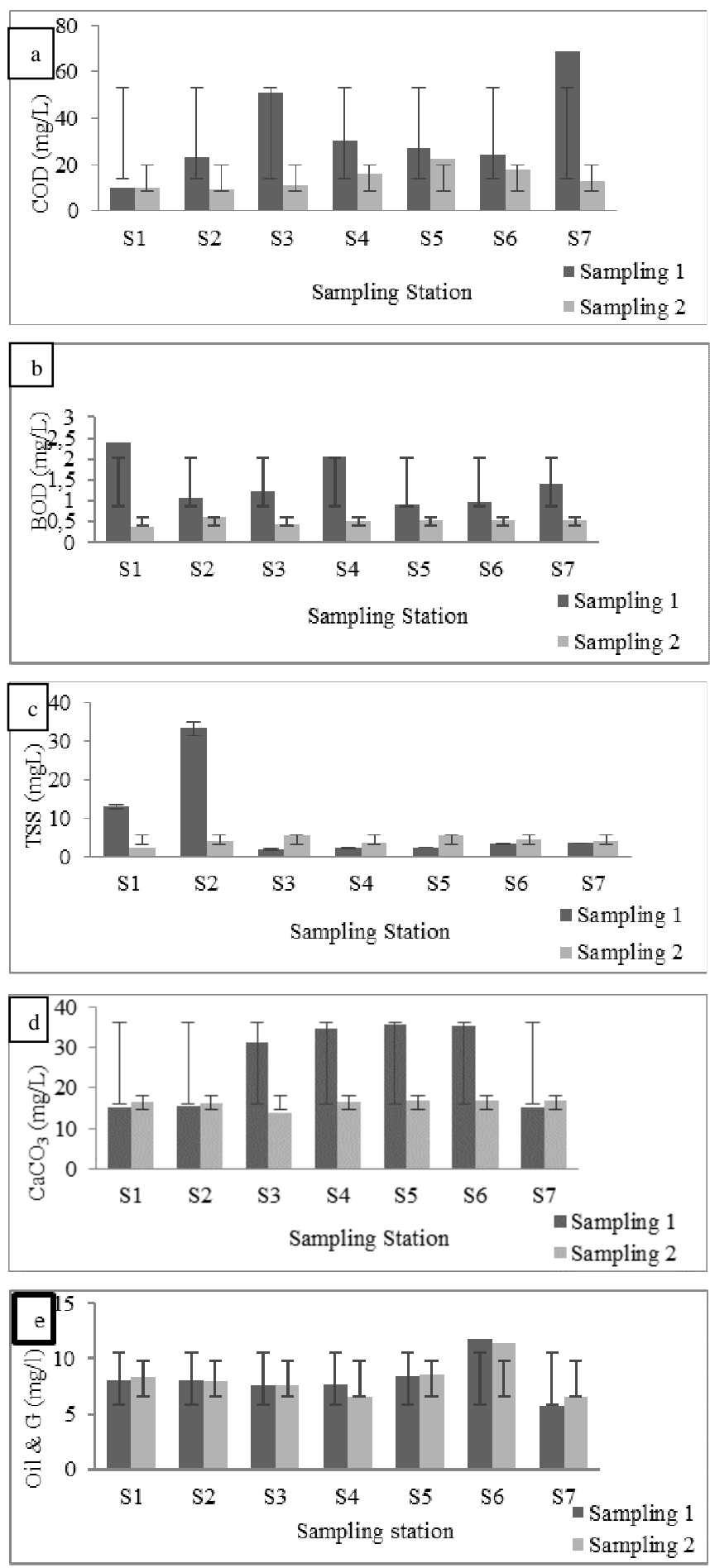

Fig. 4 Distribution of COD (a), BOD (b), TSS (c), Hardness (d) and O\&G (e) between two samplings

\section{K. Phosphate $\left(\mathrm{PO}_{4}\right)$}

The range of phosphate during the first sampling was from 0.24 to $0.56 \mathrm{mg} / \mathrm{L}$ with an average of $0.36 \mathrm{mg} / \mathrm{L}$. The highest $(0.56 \mathrm{mg} / \mathrm{L})$ was recorded at station 1 and the lowest $(0.24 \mathrm{mg} / \mathrm{L})$ was recorded at station 5 . The range of phosphate during the second sampling was from 0.21 to 0.44 $\mathrm{mg} / \mathrm{L}$ with an average of $0.31 \mathrm{mg} / \mathrm{L}$. The highest $(0.44$ $\mathrm{mg} / \mathrm{L})$ was recorded at station 2 and the lowest $(0.21 \mathrm{mg} / \mathrm{L})$ was recorded at station 5 (Fig. 5b).

\section{Sulphate $\left(\mathrm{SO}_{4}\right)$}

The range of sulphate during the first sampling was from 21 to $35 \mathrm{mg} / \mathrm{L}$ with an average of $18.05 \mathrm{mg} / \mathrm{L}$. The highest $(35 \mathrm{mg} / \mathrm{L})$ was recorded at station 2 and the lowest (21 $\mathrm{mg} / \mathrm{L})$ was recorded at stations 4 and 7 . The range of sulphate during the second sampling was from 18 to 22.6 $\mathrm{mg} / \mathrm{L}$ with an average of $19.62 \mathrm{mg} / \mathrm{L}$. The highest $(22.6$ $\mathrm{mg} / \mathrm{L})$ was recorded at station 1 and the lowest $(18 \mathrm{mg} / \mathrm{L})$ was at station 6 (Fig. 5c).
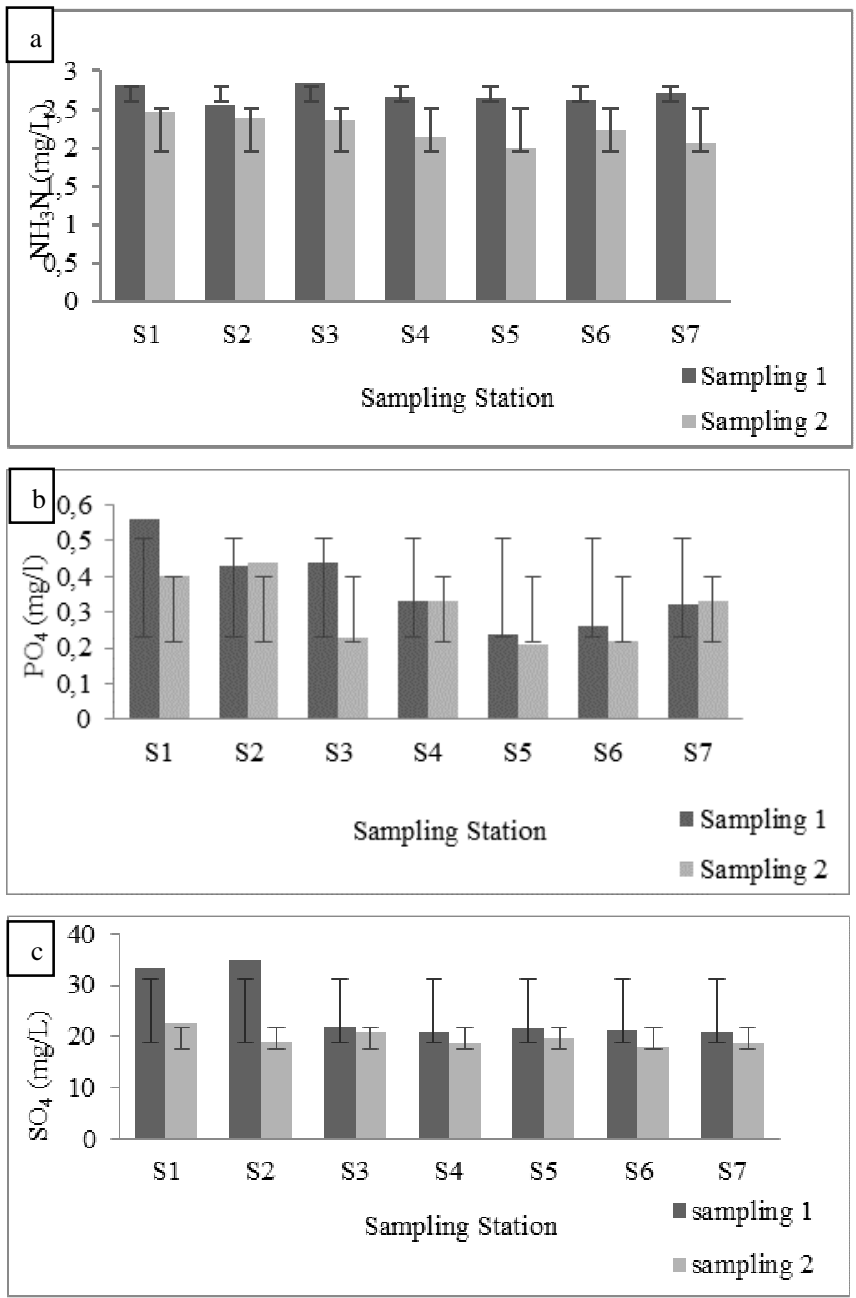

Fig. 5 Distribution of ammoniacal nitrogen (a), phosphate (b) and sulphate (c) between two samplings

\section{Temperature}

The highest temperature is $28.37^{\circ} \mathrm{C}$, at stations 3 and 7. This reading may result from the high level of exposure to the sun at this point of time and station 7's river bank is basically an exposed land whereas the lowest temperature was $26.02^{\circ} \mathrm{C}$ at station 1 , which is surrounded by vegetation like grasses and bushes that made the surrounding temperature cooler than the other stations. Temperature is a measure of the degree of hotness or coldness of a substance, rate of biochemical and chemical reactions in the water body, reduction in solubility of gases and amplifications of tastes and odours of water [27].

Several factors which are affected by weather variations and may influence the water temperature, sampling time and location were taken considerably. The statistical analysis showed that there were significant differences in the mean 
temperature levels between stations and between the sampling times (ANOVA, $\mathrm{p}<0.05, \mathrm{p}<0.05$ ). The temperature values were recorded at the Cempaka Lake, Bangi and were classified as normal based on the NWQS and classified as Class I.

\section{N. $p H$}

The mean $\mathrm{pH}$ value of the Cempaka Lake is indicated as slightly acidic. The acidity of the Cempaka Lake may also be due to the free carbon dioxide as well as the various acids and alkalis which can penetrate the water bodies that came along with the industrial wastewater. Low $\mathrm{pH}$ at stations 1 and 2 was probably due to the rainfall and runoffs from the nearby roads and surrounding areas and attributed to the presence of high organic matter resulting from the discharge of organic matter into the lake from the food processing industries [21]. The $\mathrm{pH}$ values of the lake in this study are not different compared to the values that have been by [21] in the study of Varsity Lake, University of Malaya, Kuala Lumpur which was from 5.8 to 6.9 . This could be contributed by the water from the engineering faculty that recorded as the lowest $\mathrm{pH}$.

The $\mathrm{pH}$ value was ideal when compared to the NWQS and classified as Class I. The statistical analysis showed that there were no significant differences in the mean $\mathrm{pH}$ levels between stations and between the sampling times (ANOVA, $p$ $>0.05, \mathrm{p}>0.05$ ).

\section{O. $D O$}

The DO value was higher during the first sampling compared to the second sampling and there was raining during the first sampling. In [16] reported lower values of dissolved oxygen in summer months due to a higher rate of decomposition of organic matter and limited flow of water in low oxygen holding environment due to the high temperature. The DO values of the lake in this study are higher compared to the values that have been by [8] in the study of Tasik Chini, Pahang, Malaysia which was from 0.6 to $6.4 \mathrm{mg} / \mathrm{L}$.

According to NWQS, Cempaka Lake falls under Class III. The statistical analysis of this study showed that there were no significant differences of the mean DO levels with the sampling stations, but there were significant differences between the sampling times (ANOVA, $\mathrm{p}>0.05$, $\mathrm{p}<0.05$ ).

\section{P. EC}

The average of two samplings of conductivity in the study area was $161 \mu \mathrm{S} / \mathrm{cm} \pm 38.56$. The conductivity values at the first sampling were higher than the second sampling and this showed the effect of rain which decreases the concentration of all minerals, salts or any other factors which can increase the conductivity. The higher conductivity values for Cempaka Lake might be due to the discharge from factories and settlements located along Air Hitam River.

Based on the NWQS, the level of conductivity in the study area is classified as Class I. The results showed that the lake has a higher concentration of conductivity compared to the lake Putrajaya by [4], which was from 40.7 to $152.6 \mu \mathrm{S} / \mathrm{cm}$. The statistical analysis showed that there were no significant differences of the mean of conductivity levels with the sampling stations and between the sampling times (ANOVA, p > 0.05, p > 0.05).

\section{Q. $C O D$}

The Chemical Oxygen Demand is useful as an indicator of organic pollution for surface water [20]. In this study, the level of COD conducted in all samplings was high especially at station 7 during the first sampling. Increases in the COD levels in waters are attributed to the increase of organic matter and inorganic chemicals [21] due to runoff from the restaurants, food waste and wastewater from areas around the lake. Station 7 was located at the end of the lake and received water, which comes from the entire lake. The statistical analysis in this study showed that there were significant differences of the mean of COD concentration levels within the sampling stations and the sampling times (ANOVA, $p<0.05, \mathrm{p}<0.05$ ). Based on the NWQS, the level of COD measured at all the stations in the lake was classified as Class II. Yet, the COD values of the lake in this study are not different compared to the values that have been by [22] Lake Engineering in Universiti Kebangsaan Malaysia, which was from 51.09 to $64.37 \mathrm{mg} / \mathrm{L}$. The high COD values reflect as a result from wastes disposal.

\section{R. $B O D$}

The amount of BOD exerted depends on the type and amount of organic chemicals present, numbers and types of organisms in the water, temperature, $\mathrm{pH}$, presence of nutrients and trace elements that are necessary for growth and many other environmental factors. The higher BOD, there are more organic matters in the water. At station 1, there was no rain as well as the fast movement of the water in the lake. This provided more chances for the microorganism to decompose the organic matter and this would increase the population of the microorganism.

In this case, the level of the microorganism was less than the other. The statistical analysis in this study showed that there were no significant differences of the mean of BOD concentration levels with the sampling stations, but there were significant differences of the mean of BOD concentration levels between the sampling times (ANOVA, $\mathrm{p}>0.05, \mathrm{p}<0.05)$. Based on the NWQS, the BOD of the Cempaka Lake, Bangi was classified as Class I. It is an empirical test to measure the amount of oxygen used by the microorganisms in the aerobic oxidation, or breakdown of organic matter in the lake. However, when comparing the obtained result in the current study with data obtained from other studies such as a study which was done by [19]. A study of Engineering Lake the value of BOD 0.49 to $3.48 \mathrm{mg} / \mathrm{L}$, classified as class II.

\section{S. TSS}

The average of two samplings of the total suspended solids in the study area was $6.75 \mathrm{mg} / \mathrm{L} \pm 2.50$ as shown in Fig. 4c. The statistical analysis showed that there were no significant differences of the mean of TSS concentration levels with the sampling stations, and between the sampling times (ANOVA, $p>0.05, p>0.05$ ). The results of TSS are low during the second sampling but high at station 1 and 2 during the first sampling, because there was raining, was stimulated runoff and lead to a strong rate of soil erosion and 
contributing to the increase in solid suspended in the area of flat land. Based on the NWQS, the level of TSS in the study area is classified as Class I. However, the results showed that the lake has a convergent concentration of TSS compared to the Tasik Chini, Pahang, Malaysia by [8], which was from 1.2 to $34.0 \mathrm{mg} / \mathrm{L}$.

\section{T. Hardness}

The average of two samplings of hardness in the study area was $24.63 \mathrm{mg} / \mathrm{L} \pm 11.22$ as shown in Fig. $4 d$. The statistical analysis showed that there were no significant differences in the mean hardness concentration levels with the sampling stations, but significantly differences between the sampling times (ANOVA, $\mathrm{p}>0.05, \mathrm{p}<0.05$ ).

All sampling stations measured had a similar concentration in the second sampling, but in the first sampling, it recorded a higher value from station 3 to 6 . Compared to the NWQS, the level of hardness was very low and it is classified as Class I which represents the natural level of supporting aquatic lives. The results showed that the lake has a higher concentration of hardness compared to the study by [16] in the Gundolav Lake at Kishangarh, which was from 180.6 to $327.2 \mathrm{mg} / \mathrm{L}$.

\section{$U . O \& G$}

The average of two samplings of oil and grease in the study area was $8.14 \mathrm{mg} / \mathrm{L} \pm 0.03$ as shown in Fig. $4 \mathrm{~d}$. Statistical analysis showed that there were significant differences of the mean of oil and grease value between sampling stations, but there were no significant differences between the sampling times (ANOVA, $\mathrm{p}<0.05, \mathrm{p}>0.05$ ) respectively.

A number of potential sources for this contaminant, especially the vehicle service stations, hotels, and restaurants are located close to the lake. Compared to the NWQS, the level of oil and grease was very low and classified as Class I which represents the natural level of supporting aquatic lives. The result of oil and grease in this study was lower when compared to the value obtained by [22] in the study of Varsity Lake, University of Malaya, Kuala Lumpur which ranged from 232 to $291 \mathrm{mg} / \mathrm{L}$. High concentration of the oil and grease particles are washed through kitchens, restaurants or cafeteria sinks or floor drains.

\section{V. $\mathrm{NH}_{3} \mathrm{~N}$}

The average of two sampling of $\mathrm{NH}_{3} \mathrm{~N}$ in the study area was $2.46 \mathrm{mg} / \mathrm{L} \pm 0.32$ as shown in Fig. 5a. The statistical analysis in this study showed that there were no significantly differences of the mean of $\mathrm{NH}_{3} \mathrm{~N}$ concentration levels within the sampling stations, but significantly differences between the sampling times (ANOVA, $\mathrm{p}>0.05, \mathrm{p}<0.05$ ). The NWQS recommended a threshold level of ammoniacal-nitrogen for the Malaysian surface water is $0.90 \mathrm{mg} / \mathrm{L}$ for the support of aquatic life and supply water for potable, industrial and agriculture use.

Based on the NWQS, the ammoniacal-nitrogen in Cempaka Lake, Bangi is classified as Class IV. The potential sources for this contaminant, especially from nearby residential, petrol service stations, hotels, and restaurants are located close to the lake. However, when comparing the obtained result in the current study with data obtained from other studies such as a study which was done by [23]. The value of ammoniacal nitrogen for nine sampling stations in Chini Lake during different seasons ranged from 0.003 to $0.57 \mathrm{mg} / \mathrm{L}$ or at an average of $0.17 \mathrm{mg} / \mathrm{L}$. The highest concentration was during the wet season, the lowest concentration was during the dry season.

\section{W. Phosphate}

The average of two samplings of phosphate in the study area was $0.30 \mathrm{mg} / \mathrm{L} \pm 0.03$ as shown in Fig. 5b. Higher phosphate concentrations were identified at stations 1 and 2 during both samplings, presumably due to the human activities such as residential, restaurants, hotels and clinics. In this study, the statistical analysis showed that there were significant differences of the mean of phosphate concentrations levels within the sampling stations, but no significant differences between the sampling times (ANOVA, p < 0.05, p > 0.05).

The level of phosphate concentration was low during the second sampling. Based on the NWQS, the level of phosphate measured at the study area is classified as Class I. The result of phosphate in this study was convergent compared to the value obtained by [22] in the study of Varsity Lake, University of Malaya, Kuala Lumpur which ranged from 0.2 to $33 \mathrm{mg} / \mathrm{L}$. The maximum concentration of phosphate in the water comes from the biomedical and chemical engineering departments.

\section{Sulphate}

The average of two samplings of sulphate in the study area was $18.58 \mathrm{mg} / \mathrm{L} \pm 0.46$ as shown in Fig. 5c. The statistical analysis showed that there were no significant differences of the mean of sulphate concentration levels with the sampling stations, but significantly differences between the sampling times (ANOVA, p > 0.05, p < 0.05).

The main source of sulphate was from the domestic, waste discharge such as detergent from the nearby residential and commercials areas [24]-[26]. Based on the NWQS, the concentration of sulphate $\left(\mathrm{SO}_{4}\right)$ was within the average of natural level and the lake would be classified at Class I. The sulphate values of the lake in this study are higher compared to the value obtained by [8] in the study of the Tasik Chini, Pahang, Malaysia which was from 0.00 to $2.00 \mathrm{mg} / \mathrm{L}$.

\section{CONCLUSION}

Results of the study indicated that the mean concentrations of some parameters such as the $\mathrm{pH}$, conductivity, TSS, BOD, sulphate, phosphate, hardness, oil and grease from two different samplings were within the normal range and are classified under Class I. The mean temperature and COD are classified under Class II, but the DO is classified under Class III and ammoniacal-nitrogen under Class IV. The calculated WQI values were confirmed that the lake can be classified under Class II and III for all sampling stations. The results clearly showed that the majority of the water quality parameters are more polluted during the first sampling compared to the second sampling.

Based on the statistical analysis, pH, EC, and TSS showed no significant differences; temperature and COD show significant differences; DO, BOD, hardness, ammoniacal-nitrogen significant during sampling times, while $\mathrm{O} \& \mathrm{G}$, phosphate and sulphate significant between sampling stations. 
The water body in the study area was contaminated may probably originate from the surrounding area such as from residential, petrol stations especially vehicle service stations, waste discharges, domestic sewage, hotels, commercials and restaurants that are closely located to the lake. These activities were generated both organic and inorganic waste and these wastes are ultimately contaminating the water bodies.

\section{ACKNOWLEDGMENT}

The authors would also like to thank East Coast Environmental Research Institute (ESERI, UniSZA) for the use of their research laboratory facilities. The authors would like to thank Assoc. Prof. Dr. Azizah Endut and Dr. Fathurrahman Lananan for the willingness to read and editing this manuscript.

\section{REFERENCES}

[1] J. Yisa and T. Jimoh, "Analytical studies on water quality index of River Landzu," American Journal of Applied Sciences, vol. 7, pp. 453-458, Jan. 2010.

[2] G. R. Munavalli and M. S. M. Kumar, "Water quality parameter estimation in a distribution system under dynamic state," Water Research, vol. 39, pp. 4287-4298, Nov. 2005.

[3] M. B. Gasim, N. Zakaria, R. Umar, and A. D. Mustafa, "Analisis kualiti air fiziko-kimia dan kandungan mikrob di Hulu Sungai Langat, Selangor," Malaysian Journal of Analytical Sciences, vol. 19, pp. 1072-1083, 2015.

[4] M. B. Gasim, M. E. Toriman, S. Muftah, A. Barggig, N. A. A. Aziz, F. Azaman, N. Hairoma, and H. Muhamad, Water quality degradation of Cempaka Lake, Bangi, Selangor, Malaysia as an impact of excessive E. Coli and nutrient concentrations," Malaysian Journal of Analytical Sciences, vol. 19, pp. 1391-1404, 2015.

[5] M. B. Gasim, N. H. Ariffin, H. Muhamad, and N. Hairoma, "The influence of tidal activities on water quality of Marang River, Terengganu, Malaysia," Malaysian Journal of Analytical Sciences, vol. 19, pp. 1431-1447, 2015.

[6] M. K. Mustapha, "Assessment of the water quality of Oyun Reservoir, Offa, Nigeria, using selected physico-chemical parameters," Turkish Journal of Fisheries and Aquatic Sciences, vol. 8, pp. 309-319, Aug. 2008.

[7] Y. H. Lee, M. H. Shahril, H. Y. M. Fauzan, C. Y. Lim, and A. G. Lim, "The water quality of streams at the watershed of the Putrajaya wetlands," in Proc. RSENAR'02, 2002, p. 553.

[8] M. B. Gasim, M. E. Toriman, A. Abas, M. S. Islam, and T. C. Chek, "Water quality of several feeder rivers between two seasons in Tasik Chini, Pahang," Sains Malaysiana, vol. 37, pp. 313-321, 2008.

[9] M. B. Gasim, M. E. Toriman, S. Abdrahim, M. S. Islam, T. C. Chek, and H. Juahir, "Hydrology and water quality and land-use assessment of Tasik Chini's Feeder Rivers, Pahang Malays," Geografia: Malaysian Journal of Society and Space, vol. 3, pp. 1-16, 2006.

[10] M. B. Gasim, O. M. Shuhaimi, and T. C. Chek, "Total flows contribution of the Tasik Chini feeder river and its significant water level, Pahang, Malaysia," in Proc. ITB-UKM JSC'05, 2005, p. 543.

[11] M. G. Abdullahi, M. K. A. Kamarudin, M. E. Toriman, M. B. Gasim, A. Endut, and I. Garba, "Assessment of natural groundwater recharge in Terengganu, Malaysia," International Journal on Advanced Science, Engineering and Information Technology, vol. 6, pp. 781786, Oct. 2016.
[12] C. R. Ramakrishnaiah, C. Sadashivaiah, and G. Ranganna, "Assessment of water quality index for the groundwater in Tumkur Taluk, Karnataka State, India," E-Journal of Chemistry, vol. 6, pp. 523-530, 2009.

[13] P. N. Rajankar, S. R. Gulhane, D. H. Tambekar, D. S. Ramteke, and S. R. Wate, "Water quality assessment of groundwater resources in Nagpur Region (India) based on WQI," E-Journal of Chemistry, vol. 6, pp. 905-908, 2009.

[14] G. Ankley and L. Burkhard, "Identification of surfactants as toxicants in a primary effluent," Environmental Toxicology and Chemistry, vol. 11, pp. 1235-1248, Sep. 1992.

[15] M. R. Mahananda, B. P. Mohanty, and N. R. Behera, "Physicochemical analysis of surface and group water of Bargarh District, Orissa, India," International Journal of Research and Reviews in Applied Sciences, vol. 2, pp. 284-295, 2010.

[16] A. Sharma, M. M. Ranga, and P. C. Sharma, "Water quality status of historical gundolav lake at Kishangarh as primary data for sustainable management, South Asian Journal of Tourism and Heritage, vol. 3, pp. 549-558, 2010.

[17] M. Maity and R. Banerjee, "Physico-chemical and microbiological study of some water bodies in two economically important cities," International Journal of Water Research, vol. 6, pp. 20-25, Jun. 2016.

[18] American Public Health Association (APHA), Standard Methods for Study of Examination of Water and Waste Water Analysis, 20th ed., Washington DC, USA: APHA, 1998.

[19] A. A. Olajire and F. E. Imeokparia, "Water quality assessment of Osun River: Studies on inorganic nutrients," Environmental Monitoring and Assessment, vol. 69, pp. 17-28, Jun. 2001.

[20] S. Sarmani, "The determination of heavy metals in water, suspended materials and sediments from Langat River, Malaysia," Hydrobiologia, vol. 176, pp. 233-238, 1989.

[21] N. Charalampous, A. Kindou, D. Vlastos, V. Tsarpali, M. Antonopoulou, I. Konstantinou, and S. Dailianis, "A multidisciplinary assessment of river surface water quality in areas heavily influenced by human activities," Archives of Environmental Contamination and Toxicology, vol. 69, pp. 208-222, Aug. 2015.

[22] M. A. Ashraf, M. J. Maah, and I. Yusoff, "Water quality characterization of Varsity Lake, University of Malaya, Kuala Lumpur, Malaysia," E-Journal of Chemistry, vol. 7, pp. S245-S254, 2010 .

[23] I. Mushrifah, M. S. Othman, A. Ahmad, and E. C. Lim, "Seasonal influence on water quality and heavy metals concentration in Tasik Chini, Peninsular Malaysia," in Proc. WLC'08, 2008, p. 300-303.

[24] M. K. A. Kamarudin, M. Idris, and M. E. Toriman, "Analysis of Leptobarbus hoevenii in control environment at natural lakes," American Journal of Agricultural and Biological Science, vol. 8, pp. 142-148, 2013.

[25] H. M. Din, M. E. Toriman, M. Mokhtar, R. Elfithri, N. A. A. Aziz, N. M. Abdullah, and M. K. A. Kamarudin, Loading concentrations of pollutant in Alur Ilmu at UKM Bangi campus: Event mean concentration (EMC) approach, Malaysian Journal of Analytical Sciences, vol. 16, pp. 353-365, 2012.

[26] A. F. Kamaruddin, M. E. Toriman, H. Juahir, S. M. Zain, M. N. A. Rahman, M. K. A. Kamarudin, and A. Azid, "Spatial characterization and identification sources of pollution using multivariate analysis at Terengganu River Basin, Malaysia,” Jurnal Teknologi, vol. 77, pp. 269-273, 2015.

[27] N. A. Wahab, M. K. A. Kamarudin, M. B. Gasim, R. Umar, F. M. Ata, and N. H. Sulaiman, "Assessment of total suspended sediment and bed sediment grains in upstream areas of Lata Berangin, Terengganu," International Journal on Advanced Science, Engineering and Information Technology, vol. 6, pp. 757-763, Oct. 2016. 